\title{
FORMULASI SEDIAAN KRIM ANTIINFLAMASI EKSTRAK ETANOL DAUN RAMBUSA (Passiflora foetida L)
}

\section{Cream Formulation Antiinflamatory Ethanol Extracts Of Rambusa (Passiflora foetida L)}

\section{Evi Mulyani"* \\ Halida Suryadini \\ Rizka Rahmadina $\mathbf{P}^{3}$ \\ *IUniversitas Muhammadiyah Palangkaraya, Palangka Raya, Kalimantan Tengah, Indonesia \\ 2 Universitas Muhammadiyah Palangkaraya, Palangka Raya, Kalimantan Tengah, Indonesia \\ 3 Universitas Muhammadiyah Palangkaraya, Palangka Raya, \\ Kalimantan Tengah, Indonesia \\ *email: evimulyani@umpr.ac.id}

\section{Kata Kunci:}

Rambusa

Krim

Antiinflamasi

Keywords:

Rambusa

Cream

Antiinflamation

\begin{abstract}
Abstrak
Rambusa (Passiflora foetida L) adalah tumbuhan obat yang banyak terdapat di berbagai daerah di Indonesia, termasuk di Kalimantan Tengah yang secara empiris Rambusa digunakan sebagai antibakteri dan antiinflamasi. Penelitian sebelumnya menunjukan kandungan daun Rambusa (Passiflora foetida Linn) asal Kalimantan Tengah salah satunya steroid yang memiliki sifat antiinflamasi. Tujuan dalam penelitian ini adalah untuk mengetahui apakah ekstrak etanol daun rambusa ini dapat diolah menjadi sediaan krim antiinflamasi dan untuk mengetahui hasil uji fisik yaitu uji organoleptis, uji homogenitas, uji daya sebar dan uji $\mathrm{pH}$. Penelitian ini dilakukan dengan metode peleburan. Hasil penelitian menunjukan bahwa ketiga krim ekstrak etanol daun rambusa (Passiflora foetida L) sudah memenuhi persyaratan sifat fisik homogenitas, daya sebar dan $\mathrm{pH}$.
\end{abstract}

\begin{abstract}
Rambusa (Passiflora foetida $L$ ) is a medicinal plant that is widely found in various regions in Indonesia, including in Central Kalimantan. Rambusa is empirically used as an antibacterial and anti-inflammatory. Previous research has shown that the content of Rambusa (Passiflora foetida Linn) leaves from Central Kalimantan is one of the steroids which has anti-inflammatory properties. The purpose of this study was to determine whether the ethanol extract of rambusa leaves can be processed into anti-inflammatory cream preparations and to determine the results of physical tests, namely organoleptic tests, homogeneity tests, dispersibility tests and $\mathrm{pH}$ tests. This research was conducted by smelting method. The results showed that the three creams of ethanol extract of rambusa leaf (Passiflora foetida L) had met the requirements for physical properties of homogeneity, spreadability and $\mathrm{pH}$.
\end{abstract}

\section{PENDAHULUAN}

Inflamasi sering terjadi pada bagian luar tubuh akibat benturan benda tumpul, luka, dan lain sebagainya yang dapat terlihat pada permukaan kulit. Inflamasi pada kulit terjadi karena adanya peningkatan agen proinflamasi seperti sitokin TNF-a, IL-I dan IL-6. Pada inflamasi terjadi pelepasan mediator-mediator inflamasi seperti histamin, bradikinin, serotonin dan prostaglandin (Necas, 2013). Dalam pengobatannya inflamasi yang sering terjadi pada masyarakat luas tidak terbatas pada obat-obat yang telah dijual dipasaran tapi penggunaan tanaman yang dipercaya dapat menyembuhkan inflamasi juga masih populer salah satunya adalah tanaman Rambusa (Passiflora foetida L). 
Rambusa (Passiflora foetida L) adalah salah satu jenis tanaman yang banyak ditemukan merambat pada tanaman lain. Tanaman ini biasanya ditemukan di daerah berair seperti rawa dan sungai (Lim, 20I2). Secara ilmiah tanaman ini sudah dibuktikan manfaatnya dalam penanganan masalah dalam kesehatan, Quattrocchi (20I2) menyebutkan daun rambusa berkhasiat meredakan panas, insomnia, pilek, sakit kepala dan asma. Rambusa memiliki aktivitas antiiflamasi, antitumor, antikanker, antihepatotoksisitas dan antimikroba (Duke, 2009). Pada dosis $100 \mathrm{mg} / \mathrm{kgBB}$ ekstrak etanol daun Rambusa menghasilkan efek anti inflamasi yang sangat signifikan pada tikus (Sasikala et al., 20II).

\section{METODOLOGI}

\section{Alat}

Timbangan analitik, pompa vakum, corong buchner, rotary evaporator, peralatan gelas ukur (pirex), beaker glass, mortir, stemper, jangka sorong, stopwatch, oven, pipet tetes, cawan penguap.

\section{Bahan}

Ekstrak etanol daun rambusa $1 \%, 2 \%$, dan 3\%, etanol $96 \%$, trietanolamina, asam stearat, parafin liquidum, adeps lanae, nipagin, nipasol, dan aquadestilas

\section{Metode Pelaksanaan}

\section{Ekstraksi}

Daun Rambusa (Passiflora foetida L) dikumpulkan dalam kondisi segar. Disortasi basah kemudian dicuci pada air yang mengalir dan dikeringkan menggunakan oven. Setelah kering, simplisia di haluskan dengan cara di blender. Kemudian dilakukan perendaman menggunakan ethanol $96 \%$ selama $2 \times 24$ jam, Maserat yang dihasilkan kemudian disaring dan di evaporator untuk mendapatkan ekstrak kental.

\section{Formulasi}

Tabel I. Formulasi krim ekstrak ethanol daun Rambusa (Passiflora foetida L)

\section{Bahan} Formula

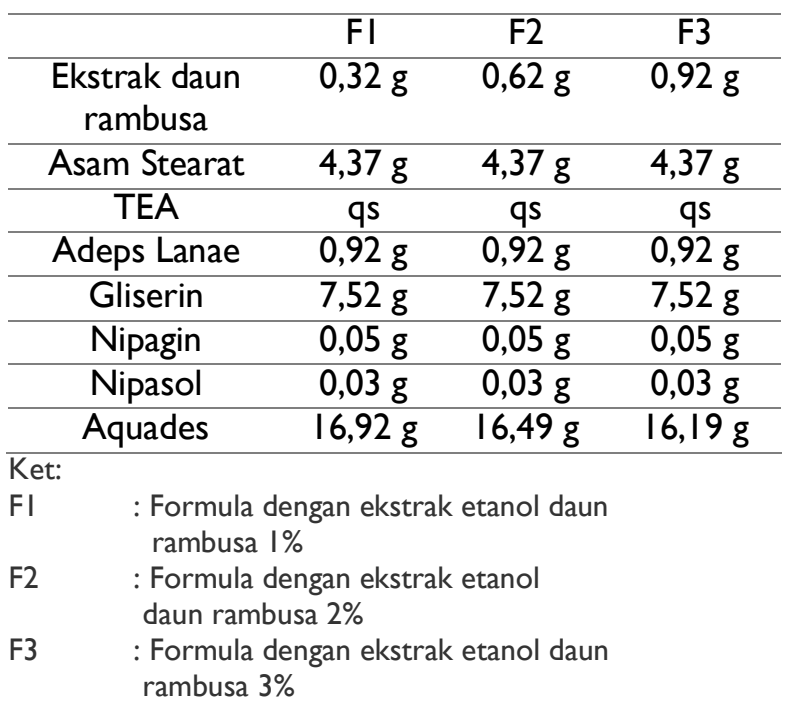

\section{Pembuatan Sediaan Krim}

Basis krim yang dibuat terdiri dari dua fase, yaitu fase minyak (parafin cair, adeps lanae, asam stearat) dan fase air (nipagin dan nipasol). Setiap fase dipanaskan pada suhu $60-70{ }^{\circ} \mathrm{C}$ di tangas air. Fase minyak dipindahkan ke dalam lumpang panas dan tambahkan fase air diaduk sampai dingin hingga terbentuk massa krim (lampiran 2). Pada bahan trietanolamin, dimasukkan dengan cara di teteskan saat kedua fase dicampurkan, pada basis krim formula I trietanolamin diteteskan sebanyak 3 tetes, pada basis krim formula 2 trietanolamin diteteskan sebanyak 4 tetes dan pada basis krim formula 3 diteteskan sebanyak 5 tetes.

\section{Evaluasi Sifat Fisik}

I. Uji Organoleptis

Uji organoleptis dilakukan dengan menggunakan indera meliputi bau, warna dan bentuk krim.

2. Uji Homogenitas

Uji homogenitas dilakukan dengan cara : sediaan ditimbang $0,1 \mathrm{~g}$ kemudian dioleskan secara merata dan tipis pada kaca obyek. Krim harus menunjukkan susunan yang homogen dan tidak terlihat adanya bintik - bintik.

3. Uji Daya Sebar

Sebanyak 0,5 g krim ditimbang dan diletakkan di atas cawan petri dan diletakkan di atas kertas grafik, kemudian letakkan kaca diatas cawan petri 
tersebut biarkan selama I menit, dihitung luas daerah yang diberikan sediaan. Selanjutnya diberi beban masing - masing 50, 100 , $150 \mathrm{~g}$ dibiarkan selama I menit selanjutnya dihitung luas sediaan yang dihasilkan pada tiap formula dilakukan replikasi sebanyak 3 kali

4. $\mathrm{Uji} \mathrm{pH}$

Krim di oleskan pada $\mathrm{pH}$ stik universal kemudian dibandingkan hasilnya dengan standar warna yang terdapat pada kemasan. Dicatat $\mathrm{pH}$ krim. Pada tiap formula dilakukan replikasi sebanyak 3 kali.

\section{HASIL DAN PEMBAHASAN}

Bahan dasar krim terdiri dari fase air dan fase minyak yang dicampur dengan zat pengemulsi (emulgator) hingga membentuk basis krim. Formulasi sediaan krim minyak dalam air (M/A) pada penelitian ini dilakukan pembuatan basis krim tipe M/A dilakukan sesuai dengan komposisi formulasi yang tertera pada tabel 2 yaitu menggunakan ekstrak daun rambusa sebagai zat aktif dengan 3 (tiga) konsentrasi berbeda yaitu I\%, 2\% dan 3\% dimana ekstrak daun rambusa ini dipercaya memiliki kandungan alkaloida, tanin, saponin, dan steroid (Mulyani, 2019) yang memiliki efek antiinflamasi.

Krim tipe M/A (Vanishing cream) merupakan suatu krim yang dibuat dengan mendispersikan komponen minyak ke dalam komponen air. Mudah dicuci dengan air dan jika digunakan di kulit akan terjadi penguapan dan peningkatan konsentrasi dari suatu obat yang larut air sehingga akan mendorong penyerapan ke dalam jaringan kulit (Aulton, 2002). Tipe krim minyak dalam air dapat memberikan efek hidrasi pada kulit. Efek hidrasi dapat meningkatkan permeabilitas kulit sehingga penetrasi obat meningkat dan mengurangi resiko timbulnya peradangan (Dermawan et al., 2015).

Hasil pengamatan organoleptis, homogenitas, $\mathrm{pH}$ dan daya sebar pada krim tipe M/A ekstrak daun Rambusa yang telah dibuat memberikan hasil sebagai berikut:
I. Hasil uji organoleptis

Uji organoleptis dimaksudkan untuk melihat tampilan fisik sediaan yang meliputi bentuk, warna dan bau. Uji organoleptis dilakukan dengan pengamatan secara visual yaitu dengan cara mengamati terjadinya perubahan warna, perubahan bau, pemisahan fase (Utami, 20I2)

Tabel 2. Hasil pengamatan organoleptis krim ekstrak etanol daun rambusa (Passiflora foetida Linn)

\begin{tabular}{llll}
\hline \multicolumn{1}{c}{ Kriteria } & FI & F2 & F3 \\
\hline Warna & Hijau & Hijau & Hijau \\
Bau & Khas & Khas & Khas \\
Pemisahan fase & Tidak & Tidak & Tidak \\
\hline
\end{tabular}

Warna yang dihasilkan merupakan warna hijau yang berasal dari ekstrak etanol daun rambusa,

2. Hasil uji homogenitas

Tabel 2. Hasil pengamatan organoleptis krim ekstrak etanol daun rambusa (Passiflora foetida Linn)

\begin{tabular}{llll}
\hline \multicolumn{1}{c}{ Kriteria } & FI & F2 & F3 \\
\hline Tercampur rata & $\sqrt{ }$ & $\sqrt{ }$ & $\sqrt{ }$ \\
Butiran kasar & - & - & - \\
\hline
\end{tabular}

Menurut Ditjen POM RI (1979), pengamatan homogenitas dapat dilakukan dengan mengoleskan sediaan pada sekeping kaca atau bahan transparan lain, lalu diratakan, jika tidak ada butiran-butiran maka sediaan dapat dikatakan homogen. Dari percobaan yang telah dilakukan pada sediaan krim ekstrak daun rambusa tidak diperoleh butiranbutiran pada objek gelas seperti yang terlihat pada lampiran 4, maka sediaan krim tersebut dikatakan homogen.

3. Hasil Uji daya sebar

Tabel 4. Hasil uji daya sebar krim ekstrak ethanol daun rambusa (Passiflora foetida Linn)

\begin{tabular}{ccc}
\hline Formula & $\begin{array}{c}\text { Rata- } \\
\text { rata }\end{array}$ & SD \\
\hline FI & 5,0 & 0,76 \\
F2 & 5,1 & 0,75 \\
F3 & 5,4 & 0,05 \\
\hline
\end{tabular}

Uji daya sebar bertujuan untuk mengetahui kemampuan krim agar mudah diaplikasikan atau digunakan. Daya sebar yang baik membuat kontak 
antara krim dan kulit menjadi lebih luas sehingga zat aktif lebih cepat terabsorbsi. Semakin besar daya sebar krim maka zat aktif yang dihantarkan ke dalam lapisan kulit akan semakin besar (Voigt, 1995). Standar daya sebar krim yaitu $5 \mathrm{~cm}-7 \mathrm{~cm}$ (Ulaen et al, 2012; Parwanto et al, 2013; Edy et al, 2016). Krim ekstrak etanol daun rambusa ini telah memenuhi standar daya sebar.

4. Hasil Uji pH

Tabel 5. Hasil uji pH krim ekstrak ethanol daun rambusa (Passiflora foetida Linn)

\begin{tabular}{ccc}
\hline Formula & $\begin{array}{c}\text { Rata- } \\
\text { rata }\end{array}$ & SD \\
\hline FI & 6,9 & 0,057 \\
F2 & 6,7 & 0,288 \\
F3 & 7 & 0,000 \\
\hline
\end{tabular}

Nilai $\mathrm{pH}$ merupakan salah satu parameter utama untuk sediaan topikal, hal ini dikarenakan apabila sediaan tidak memiliki $\mathrm{pH}$ yang sesuai akan mengakibatkan iritasi atau menjadikan kulit kering. $\mathrm{pH}$ sediaan yang baik sesuai dengan $\mathrm{pH}$ kulit yaitu 4,5 - 6,5 (Tranggono dan Latifa, 2007; Parwanto et al, 20l3; Edy et al, 20l6). Hasil pengukuran $\mathrm{pH}$ sediaan selesai di buat adalah 7 (lampiran 5). Hal ini menunjukkan bahwa sediaan masih memiliki $\mathrm{pH}$ yang aman untuk digunakan pada kulit.

\section{KESIMPULAN}

Ekstrak etanol daun rambusa (Passiflora foetida,Linn) dapat diformulasikan menjadi sedian krim yang memiliki organoleptis khas dan memenuhi standar $\mathrm{pH}$, homogenitas, dan daya sebar.

\section{UCAPAN TERIMA KASIH}

Tim Peneliti mengucapkan terimakasih kepada Lembaga penelitian dan pengabdian masyarakat (LP2M) Universitas Muhammadiyah Palangkaraya yang telah memberikan pembiayaan terhadap penelitian ini melalui kompetisi penelitian internal dosen UMPR yang berkolaborasi dengan mahasiswa program studi D3 Farmasi.

\section{REFERENSI}

I. Necas, J \& Bartosikova, L. 2013. Carrageenan: a review. Veterinarni Medicina, 58 (4).

2. Lim, T.K. 2012. Edible Medicinal and Non-Medicinal Plants Volume 4 Fruits. New York: Springer: 166172.

3. Quattrocchi, F.L.S \& Umberto. 20I2. CRC World Dictionary of Medicinal and Poisonous Plants, Common Names, Scientific Names, Eponyms, Synonyms, and Etymology. Francis: CRC Press.

4. Duke, J.A. 2009. Medical Plants of Latin America. CFC Press. 36:501-502.

5. Sasikala, V., Saravanan, S \& Thangaraj, P. 20II. Analgesic and anti-inflammatory activities of Passiflora foetida L. Asian Pacific Journal of Tropical Medicine .4(8). DOI: 10.1016/SI9957645(II)60I55-7.

6. Mulyani, E. 2019.Studi In Vitro: Efek Anti Kolesterol Ekstrak Daun Rambusa (Passiflora foetida L). Jurnal Surya Medika, Vol. 4 No.02.

7. Dermawan, A.M., Pratiwi, L \& Kusharyanti, I. 2015. Efektivitas Krim Antijerawat Ekstrak Metanol Daun Pacar Air (Impatiens balsamina L). Traditional Medicine Journal.Vol 20(3).

8. Utami, R.E. 2012. Antibiotika Resistensi dan Rasionalitas Terapi Jurnal Fakultas Saintek Universitas Islam Negeri Maulan Malik Ibrahim Malang. El-Hayah Malang vol I no-4.

9. Ulaen, S.P.J., Banne, Y.S \& Ririn, A. 2012. Pembuatan Salep Anti Jerawat dari Ekstrak Rimpang Temulawak (Curcuma xanthoriza Roxb.). Jurnal Ilmiah Farmasi 3 (20): 45-49.

I0. Parwanto, M.L.E., Senjaya, H \& Edy, H.J. 2013. Formulasi Salep Antibakteri Ekstrak Etanol Daun Tembelekan (Lantana camara L.). PHARMACON I (I): 104-108.

II. Edy, H.J., Marchaban., Wahyuono S \& Nugroho, A.E. 2016. Formulasi dan Uji Sterilitas Hidrogel Herbal Ekstrak Etanol Daun Tagetes erecta L. PHARMACON 5 (2): 9-16. 